\title{
Publisher Correction: Circulating miR-103a-3p contributes to angiotensin II-induced renal inflammation and fibrosis via a SNRK/NF-kB/p65 regulatory axis
}

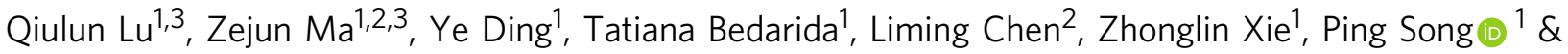
Ming-Hui Zou ${ }^{1}$

Correction to: Nature Communications https://doi.org/10.1038/s41467-019-10116-0, published online 13 May 2019.

The original version of this Article contained an error in Fig. 1 in which Fig. $1 \mathrm{~b}$ was inadvertently replaced by a duplicate of Fig. 1a. This has been corrected in the PDF and HTML versions of the Article.

Published online: 06 August 2019

\begin{abstract}
(c) Open Access This article is licensed under a Creative Commons Attribution 4.0 International License, which permits use, sharing, adaptation, distribution and reproduction in any medium or format, as long as you give appropriate credit to the original author(s) and the source, provide a link to the Creative Commons license, and indicate if changes were made. The images or other third party material in this article are included in the article's Creative Commons license, unless indicated otherwise in a credit line to the material. If material is not included in the article's Creative Commons license and your intended use is not permitted by statutory regulation or exceeds the permitted use, you will need to obtain permission directly from the copyright holder. To view a copy of this license, visit http://creativecommons.org/licenses/by/4.0/.
\end{abstract}

(c) The Author(s) 2019

\footnotetext{
${ }^{1}$ Center for Molecular and Translational Medicine, Georgia State University, Atlanta, GA, USA. ${ }^{2}$ Key Laboratory of Hormones and Development (Ministry of Health), Tianjin Key Laboratory of Metabolic Diseases, Tianjin Metabolic Diseases Hospital \& Tianjin Institute of Endocrinology, Tianjin Medical University, Tianjin, China. ${ }^{3}$ These authors contributed equally: Qiulun Lu, Zejun Ma. Correspondence and requests for materials should be addressed to Z.X. (email: zxie@gsu.edu) or to P.S. (email: psong@gsu.edu)
} 